Group discussions until lunch followed the paper and during the lunch per $L$ there were film showings and an exhibition of toys.

\title{
Final session
}

At the afternoon session four speakers: Dr. Mildred Creak, Consult "A Psychiatrist, Hospital for Sick Children, Great Ormond St., Mr. D. Evans, Sed th Psychologist, West Sussex C.G. Service, Mrs. P. Nursten, Psychiatric Social Worly Shipley and Harrogate Child Guidance Clinics, and Miss O. C. Sampson, Lecturet Education (Child Guidance) at the University of Manchester, commented briefly particular aspects of the two papers and Dr. Kahn and Dr. Pringle then elabora on these points and also answered selected questions from members of the conferet or from the groups. This form of final session seemed to be an improvement? previous years when reports back from the groups have been known to get repetiti Proof of the interest and stimulation arising from the papers was shown by the co siderable number of questions submitted in advance; many very technical and sear ing. It was only possible to pick out eight or ten representative questions but replies to these made a most rewarding afternoon.

\section{Less parochial}

As there was no immediate report back from the groups everyone is depend upon their own experience, and what they have picked up from others, for impression. The group leaders will be reporting back on the discussions for final conference report, but what did seem to be generally agreed was that groups were able to get discussion focussed around the papers more successfully th has sometimes been the case before and that there was not so much of the rath parochial kind of discussion with anecdotal illustrations about the difficult psychiat or impossible head teacher in our town. The fact that the groups went well added the general atmosphere of satisfaction on which the conference ended.

The next conference will probably be around the problems of adolescence, $b$ suggestions about future conferences were invited by the Chairman and will welcomed by the planning committee.

\section{CHILIDEN'S BILL}

THIS Bill is unusual in having been 1 presented first in the House of Lords. It reached its third reading in the Commons on 27th February. The debates have been characterised by the high level of discussion, the give and take between the government sponsors and those putting forward amendments, and its non-party character.

The principal point of difficulty is the question of raising the age of criminal responsibility. The Government wishes to raise this to 10 years old and not 12 as suggested in the amendment, because of the problems which arise in dealing with the offenders under the age of criminal responsibility. If they are brought before the court on a civil charge as in need of care, protection or control the child is deprived of the need for "proof beyond reasonable doubt" as in a criminal charge. The government spokes- man suggested that at 10 years old th child who had committed an offen would be ready to face the full rules evidence.

\section{Local authority responsibility}

One of the most important effects the Bill will be to place on local auth orities responsibility for carrying preventive work and for making advic available to families. They are enable to do this through voluntary bodies they wish to do so. The schedule of th Act puts the responsibility on the Child ren's Department and the question arise whether this is desirable or whether would not be better to leave the positio more flexible. If the responsibility wer placed on the local authority as a whol it could decide which department could best carry it out. 